\title{
Tomato Seedling Growth in Response to Variation in Root Container Shape
}

\author{
Albert Liptay and Diane Edwards \\ Agriculture Canada, Research Station, Harrow, Ont. NOR I GO, Canada \\ Additional index words. root ball, growing medium, Lycopersicon esculentum, multicelled \\ trays
}

Abstract. Roots of tomato (Lycopersicon esculentum Mill.) seedlings grown in multicelled trays were confined largely to the interface between the growing medium and the inner surface of the cell. Because of the predominance of roots in this area, experiments were done in prototype cells to relate seedling growth to change in this interface area while retaining a constant volume. The cell shapes that were tested included a square cell with 1.36-cm sides and other rectangular cells. All cells were $3 \mathrm{~cm}$ in height, but widths decreased incrementally by $0.1 \mathrm{~cm}$ from the $1.36 \times 1.36-\mathrm{cm}$ square to rectangles with inner cell dimensions of $0.36 \times 5.14 \mathrm{~cm}$. With these changing shapes, the interface area increased but cell width decreased to a more narrow cell. Seedling height increased as the cell shape was changed from a square $(1.36 \times 1.36 \mathrm{~cm})$ to an elongated rectangle $(1.74 \times 1.06 \mathrm{~cm})$. More narrow cells caused seedling height to decrease; the shortest seedlings occurred in $0.36 \times 5.14-\mathrm{cm}$ cells. Root growth was unaffected by change in cell shape. The smoothness of the inner cell surface, however, affected root growth; a rough texture resulted in stubby and reduced root growth but had no effect on shoot growth.

Root growth of tomato seedlings in multicelled trays occurs mainly around the periphery of the growing medium next to the inner wall of the cells. Jones and Haskins (1935) reported that tomato roots proliferate at this interface when plants are grown in clay pots but not in glass tumblers. In general, however, there is a lack of scientific literature on this topic.

Because roots grow at this interface, our objective was to determine whether a change in cell shape, the growing medium-cell interface area, or both would have an effect on tomato seedling growth. Liptay and Hoffmann (1988) reported the effects of changing volumes and cell sizes on tomato seedling growth; however, we found no reports of changing cell shape with retention of constant volume in the literature. During our study, it also became evident that the smoothness of the inner cell surface affected seedling root growth.

\section{Materials and Methods}

Tomato seeds were sown in modified peatmoss (ASB; ASB-Greenworld, Pointe Sapin, Canada) in prototype cells of constant volume at a particular depth but varying shapes. The first set of experiments was done in styrofoam cells. The cells were formed by custom-made copper dies inserted into the heating tip of a soldering iron. The heated dies

Received for publication 13 Sept. 1993. Accepted for publication 5 Nov. 1993. The cost of publishing this paper was defrayed in part by the payment of page charges. Under postal regulations, this paper therefore must be hereby marked advertisement solely to indicate this fact. thus, a modification was added to the cells in half of the trays to compare the effects of rough-surfaced and smooth-surfaced cells on tomato seedling growth. The rough cells were those made by the dies. A thin stiff plastic sheet was inserted around the inner sides of cells to obtain smooth cells. Seedlings were grown in a greenhouse with natural light and at $24 \mathrm{C}$ for $14 \mathrm{~h}$ during the day and $18 \mathrm{C}$ at night. We watered the plants as required, normally once a day, and fertilized them three times per week with a $20 \mathrm{~N}-20 \mathrm{P}-20 \mathrm{~K}$ fertilizer at 100 $\mathrm{mgN} /$ liter. Seedling heights, shoot dry weights, leaf areas, and root dry weights were measured on five seedlings from each of four replications after 5 weeks of growth. We analyzed data using analysis of variance.

In another experiment, more precise, smooth-surfaced cells were made of 2-mmthick acrylic plastic. The plastic cell sides and bottoms were cut and then glued together with epoxy resin glue. For all cells, the inner dimensions were $3 \mathrm{~cm}$ high and the following lengths and widths (also in centimeters): 1) $1.36 \mathrm{x}$ 1.36,2) $1.47 \times 1.26,3) 1.59 \times 1.16,4) 1.75 \times$ $1.06,5)-1.93 \times 0.96,6) 2.15 \times 0.86,7) 2.43 \times$ $0.76,8) 2.8 \times 0.66,9) 3.3 \times 0.56,10) 4.02 \times$ 0.46 , and 11) $5.14 \times 0.36$. There were 25 cells in each tray. Each cell had a 0.15 -cm-diameter drainage hole. The seedlings were grown and the five seedlings from the center of the prototype tray were measured as previously reported. Data were analyzed by regression analysis.

\section{Results and Discussion}

The roots of tomato seedlings grown in multicelled trays proliferated mostly on the
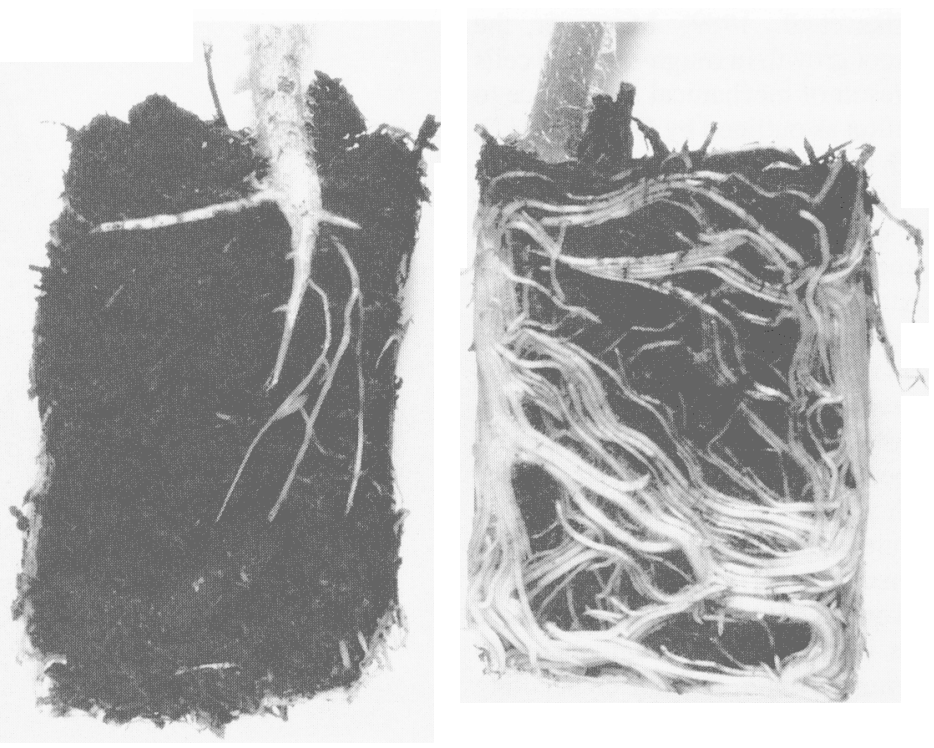

Fig. 1. Root balls of tomato seedlings. Note, on right, profusion of roots covering the outside of the growing medium on the seedling; note, on left, the presence of only a small number of root laterals growing from the main root located in the center of the root ball to the outside of the root ball. The root ball on the left was cut open and the peatmoss was brushed aside to indicate the dearth of roots within the root ball except for $\approx 5-10$ laterals that grew to the outside surface of the root ball from the main root. The seedlings were grown in acrylic plastic cells 0.96 wide $\times 1.93$ long $\times 3 \mathrm{~cm}$ deep.

were used to melt 5-cm-thick styrofoam to a in diameter was made in each cell. Trays with were constructed with each of the five dies. gidth of the dies were (both in $2.5 \times 0.74,4) 3.3 \times 0.56$, and5) $5.6 \times 0.33$. The inner surfaces of these cells were not smooth; 
periphery of the root ball at the growing medium-cell interface (Fig. 1). By 5 weeks, there were $\approx 5-10$ laterals growing from the main root outward to the cell surface. Then, most root growth took place at the interface, with the roots winding themselves around the root ball.

Cell shape, cell depth, and cell shape $x$ depth and cell shape $\mathrm{x}$ texture interactions affected shoot height (Table 1). In contrast, neither the interaction of cell shapex depth nor with cell shape alone affected shoot fresh weight and dry weight. Moreover, root growth increased with increased cell depth and was less decreased in a rough-textured than in a smooth-textured cell. The latter effect was dramatic (Fig. 2), with many of the roots in rough-surfaced cells being stubby. There were also roots on the stems of seedlings grown in rough-surfaced cells.

In the acrylic cells, seedling height increased as the cell shape was changed from a $1.36 \times 1.36-\mathrm{cm}$ square to a $1.74 \times 1.06-\mathrm{cm}$ rectangle. Plants in more narrow cells decreased in height with decreasing cell width (Table 2). The shortest seedlings occurred in $5.14 \times 0.36-\mathrm{cm}$ cells. In contrast to shoot growth, root growth was similar with all cell shapes.

The proliferation of root growth at the growing medium-cell interface is a common feature with plants grown in containers. Our results (Table 2) indicate that with a constant volume of growing medium and cell depth, a change in the physical dimensions of the cell (i.e., cell length and width; therefore, interface area) can have an effect on tomato seedling growth. However, further investigation is required to understand the cause of the root proliferation at the interface.

Enhanced root growth with increased depth of medium (Table 1) can be explained by increased aeration and volume water availability (Milks et al., 1989). Moreover, the decreased root growth in rough-textured cells is likely a result of mechanical impedance to root elongation as outlined by Dexter (1987), even though the rough-textured cells may not appear to offer much resistance to root extension. The restriction in root growth with rough-textured cells seemingly was out of proportion to the relatively low level of roughness in the cell surface. However, Russell and Goss (1974) indicated that the mechanical resistance required to reduce root growth by an initial $50 \%$ was rather low, whereas much higher impedances were required to reduce root growth $>50 \%$.

Our results indicate the importance of the growing medium-cell interface for tomato seedling growth. Future clarification of the interactions of the physical components of cells, growing medium, or both on seedling growth would help in understanding the control mechanisms of root and shoot growth in multicelled trays. Such basic information on the physical interactions of cells and seedling growth also might help to develop cultural practices such as in situ seedling hardening, i.e., acclimatization of seedlings in the greenhouse, for use as transplants in the field.
Table 1. Growth of tomato seedlings in response to change in cell shape, depth, and surface texture in prototype styrofoam cells.

\begin{tabular}{|c|c|c|c|c|c|c|c|}
\hline \multicolumn{4}{|c|}{ Cell } & \multicolumn{4}{|c|}{ Shoot } \\
\hline $\begin{array}{l}\text { Length } \\
\text { (cm) }\end{array}$ & $\begin{array}{l}\text { Width } \\
(\mathrm{cm})\end{array}$ & $\begin{array}{c}\text { Depth } \\
(\mathrm{cm})\end{array}$ & Texture $^{2}$ & $\begin{array}{c}\mathrm{Ht} \\
(\mathrm{cm})\end{array}$ & $\begin{array}{c}\text { Fresh wt } \\
(\mathrm{g})\end{array}$ & $\begin{array}{l}\text { Dry wt } \\
(\mathrm{g})\end{array}$ & $\begin{array}{c}\text { Root dry } \\
\text { wt (g) }\end{array}$ \\
\hline \multirow[t]{6}{*}{1.36} & 1.36 & 2 & $\mathrm{R}$ & 8.5 & 0.92 & 0.056 & 0.011 \\
\hline & & 2 & $S$ & 7.0 & 0.94 & 0.061 & 0.014 \\
\hline & & 3 & $\mathbf{R}$ & 8.6 & 1.29 & 0.082 & 0.016 \\
\hline & & 3 & $S$ & 8.5 & 1.28 & 0.086 & 0.015 \\
\hline & & 4 & $\mathbf{R}$ & 10.3 & 1.69 & 0.111 & 0.022 \\
\hline & & 4 & S & 9.9 & 1.30 & 0.081 & 0.018 \\
\hline \multirow[t]{6}{*}{1.70} & 1.08 & 2 & $\mathbf{R}$ & 7.8 & 0.86 & 0.056 & 0.014 \\
\hline & & 2 & $S$ & 7.8 & 0.098 & 0.067 & 0.015 \\
\hline & & 3 & $\mathbf{R}$ & 9.0 & 1.43 & 0.096 & 0.015 \\
\hline & & 3 & $\mathrm{~S}$ & 8.9 & $1: 31$ & 0.091 & 0.017 \\
\hline & & 4 & $\mathbf{R}$ & 9.7 & 1.18 & 0.071 & 0.011 \\
\hline & & 4 & $S$ & 9.2 & 1.35 & 0.089 & 0.019 \\
\hline \multirow[t]{6}{*}{2.5} & 0.74 & 2 & $\mathbf{R}$ & 8.1 & 1.10 & 0.072 & 0.016 \\
\hline & & 2 & $S$ & 7.4 & 0.09 & 0.062 & 0.018 \\
\hline & & 3 & $\mathbf{R}$ & 9.9 & 1.31 & 0.080 & 0.011 \\
\hline & & 3 & $\mathrm{~S}$ & 10.3 & 1.43 & 0.109 & 0.012 \\
\hline & & 4 & $\mathrm{R}$ & 9.8 & 1.36 & 0.088 & 0.012 \\
\hline & & 4 & $\mathrm{~S}$ & 10.8 & 1.56 & 0.106 & 0.021 \\
\hline \multirow[t]{6}{*}{3.3} & 0.56 & 2 & $\mathrm{R}$ & 9.2 & 1.13 & 0.072 & 0.012 \\
\hline & & 2 & $\mathrm{~S}$ & 6.4 & 0.90 & 0.057 & 0.013 \\
\hline & & 3 & $\mathrm{R}$ & 10.1 & 1.62 & 0.110 & 0.022 \\
\hline & & 3 & $S$ & 9.2 & 1.41 & 0.089 & 0.020 \\
\hline & & 4 & $\mathrm{R}$ & 9.8 & 2.14 & 0.150 & 0.024 \\
\hline & & 4 & $S$ & 8.1 & 1.47 & 0.090 & 0.020 \\
\hline \multirow[t]{6}{*}{5.60} & 0.33 & 2 & $\mathrm{R}$ & 6.9 & 1.02 & 0.065 & 0.012 \\
\hline & & 2 & $S$ & 7.8 & 1.21 & 0.073 & 0.012 \\
\hline & & 3 & $\mathbf{R}$ & 8.2 & 1.41 & 0.085 & 0.013 \\
\hline & & 3 & $\mathrm{~S}$ & 8.8 & 1.57 & 0.098 & 0.024 \\
\hline & & 4 & $\mathrm{R}$ & 7.5 & 1.18 & 0.065 & 0.013 \\
\hline & & 4 & $\mathbf{S}$ & 9.2 & 1.52 & 0.101 & 0.023 \\
\hline \multicolumn{2}{|c|}{ Significance } & \multicolumn{2}{|c|}{$\mathrm{df}$} & & & & \\
\hline \multicolumn{2}{|c|}{ Cell shape } & \multicolumn{2}{|c|}{4} & ** & NS & NS & NS \\
\hline \multicolumn{2}{|c|}{ Cell depth } & \multicolumn{2}{|c|}{2} & ** & $* *$ & ** & * \\
\hline \multicolumn{2}{|c|}{ Shape- $\times$ depth } & \multicolumn{2}{|c|}{8} & * & NS & NS & NS \\
\hline \multicolumn{2}{|c|}{ Texture } & \multicolumn{2}{|c|}{1} & NS & NS & NS & * \\
\hline \multirow{2}{*}{\multicolumn{2}{|c|}{$\begin{array}{l}\text { Shape } \times \text { texture } \\
\text { Depth } \times \text { texture }\end{array}$}} & \multicolumn{2}{|c|}{4} & ** & * & * & NS \\
\hline & & \multicolumn{2}{|c|}{2} & NS & NS & NS & NS \\
\hline \multicolumn{3}{|c|}{ Shape $\times$ depth $\times$ texture } & & NS & NS & NS & NS \\
\hline
\end{tabular}

${ }^{2} \mathrm{R}=$ rough $; \mathrm{S}=$ smooth.

Ns, ****Nonsignificant or significant at $P \leq 0.05$ or 0.01 by $\mathrm{F}$ test, respectively.

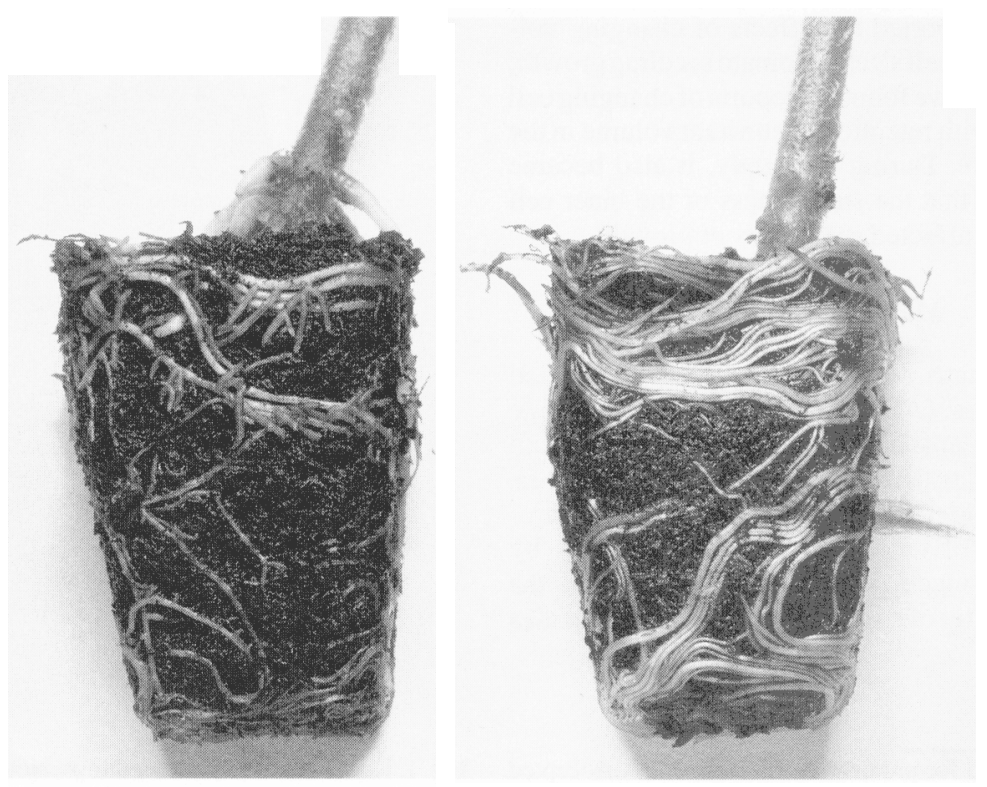

Fig. 2. Tomato seedlings grown in a cell with a (right) smooth-surfaced texture and (left) a rough-textured cell surface. Note also the roots developing on the stem of the seedling on the left. For seedling on right, the inside of the styrofoam prototype cells were lined with a rigid plastic to give a smooth texture. The cells were 3.30 wide $\times 0.56$ long $\times 3 \mathrm{~cm}$ deep. 
Table 2. Growth of tomato seedlings in response to change in cell shape in prototype acrylic cells of constant volume of $5.6 \mathrm{~cm}^{3}$ and $3-\mathrm{cm}$ depth.

\begin{tabular}{|c|c|c|c|c|c|}
\hline \multicolumn{2}{|c|}{ Cell $^{2}$} & \multirow{2}{*}{$\begin{array}{c}\text { Shoot } \\
\text { ht }(\mathrm{cm})\end{array}$} & \multirow{2}{*}{$\begin{array}{c}\text { Shoot dry } \\
\text { wt (g) }\end{array}$} & \multirow{2}{*}{$\begin{array}{c}\text { Leaf area } \\
\left(\mathrm{cm}^{2}\right)\end{array}$} & \multirow{2}{*}{$\begin{array}{r}\text { Root dry } \\
\text { wt (g) }\end{array}$} \\
\hline Length $(\mathrm{cm})$ & Width $(\mathrm{cm})$ & & & & \\
\hline 1.36 & 1.36 & 7.0 & 0.15 & 27.9 & 0.047 \\
\hline 1.47 & 1.26 & 8.1 & 0.17 & 23.3 & 0.048 \\
\hline 1.59 & 1.16 & 9.1 & 0.23 & 38.5 & 0.053 \\
\hline 1.75 & 1.06 & 9.2 & 0.22 & 30.6 & 0.052 \\
\hline 1.93 & 0.96 & 8.8 & 0.19 & 31.9 & 0.046 \\
\hline 2.15 & 0.86 & 8.4 & 0.22 & 25.3 & 0.052 \\
\hline 2.43 & 0.76 & 8.7 & 0.19 & 25.6 & 0.053 \\
\hline 2.80 & 0.66 & 8.4 & 0.17 & 23.0 & 0.050 \\
\hline 3.30 & 0.56 & 8.1 & 0.17 & 22.7 & 0,050 \\
\hline 4.02 & 0.46 & 7.5 & 0.11 & 20.9 & 0.037 \\
\hline 5.14 & 0.36 & 6.4 & 0.18 & 21.6 & 0.052 \\
\hline \multicolumn{6}{|l|}{ Significance } \\
\hline Linear & & $* *$ & $*$ & $* *$ & NS \\
\hline Quadratic & & $* *$ & $* *$ & NS & NS \\
\hline Residual & & NS & $* *$ & NS & NS \\
\hline
\end{tabular}

${ }^{2}$ All cells were $3.0 \mathrm{~cm}$ deep.

'For linear, quadratic, and residual regressions, df and error were $1,1,8$, and 33, respectively.

ws, ${ }^{*}, * * 1$ Nonsignificant or significant at $P \leq 0.05$ or 0.01 by $\mathrm{F}$ test, respectively,

\section{Literature Cited}

Dexter, A.R. 1987. Mechanics of root growth, Plant \& Soil 98:303-312.

Jones, L.H. and H.D. Haskins. 1935. Distribution of roots in porous and nonporous containers. Plant Physiol. 10:511-519.

Liptay, A. and K. Hoffmann. 1988. Extending upper cell density limits of processing tomato tray transplant production in greenhouses. Acts Hort. 230:533-540.

Milks, R. R., W.C. Fonteno, and R.A. Larson. 1989. Hydrology of horticultural substrates: III. Predicting air and water content of limited-volume plug cells. J. Amer. Soc. Hort. Sci. 114:57-61.

Russell, R.S. and M.J. Goss. 1974. Physical aspects of soil fertility: The response of roots to mechanical impedance, Neth. J. Agr. Sci. 22:305318 . 